\title{
Sorption of Zinc on Some Clay Soils in Malaysia
}

\author{
Ibrahim A. Al-Hawas ${ }^{1}$
}

\begin{abstract}
Six soil samples represent the major soil series used for agricultural production such as Rubber, oil palm, cocoa and rice in Malaysia were sampled to study the adsorption capacity of zinc which consider as an environmental harmful metal. The objectives of this study were to report experimental results on adsorption of $\mathrm{Zn}$ and to determine the adsorption mechanism of these soils using different models. After soil characterization, sorption isotherms were prepared using the six different soils and initial $\mathrm{zn}$ concentrations ranged from 5 to $100 \mathrm{mg} \mathrm{L}^{-1}$. The soils show different retention capacity. The highest sorption capacity was found in Melangit soil. Because of the presence of calcite and high $\mathrm{pH}$, the precipitation of zinc was the dominate factor. Where the high $\mathrm{Zn}$ adsorption in Kundor soil attributed to the characterization of the soil. The high CEC and the clay content were the main factors. $\mathrm{Zn}$ adsorption isotherms corresponding to all soils adjusted to Langmuir and Freundlich empirical models. Results showed that Freundlich equation has highest value of correlation coefficient $\left(\mathbf{r}^{2}\right)$ comparison to Langmuir equations and that all soils have high affinity for $\mathrm{Zn}$ sorption. Therefore the main factors controlling the adsorption of $\mathrm{Zn}$ in these alluvial soil are precipitation and ionic adsorption.
\end{abstract}

Keyword: Zn, adsorption, Langmuir, Freundlich, calcite

\section{INTRODUCTION}

The behavior of heavy metals in soils has been extensively studied, and several review concerning retention phenomena have been published during the past 10 years (Uzun, and Guzel 2000; Muhamad 1998, Igwe, et. al., 2005). Adsorption isotherm analysis is useful in studying the retention process, because it provides a macroscopic view of the retention phenomena. Retention may be due to precipitation and / or adsorption (involving several molecular mechanisms) and depends on factors such as the nature of metal, nature of mineral and organic constituent of the soil, cation exchange capacity (Shuman, 1975) and the composition of soil solution. Most micronutrients (Fe, $\mathrm{Mn}, \mathrm{Zn}, \mathrm{Cu}, \mathrm{Co}$ ) are more readily available at a low $\mathrm{pH}$. Many studies on adsorption of heavy metals by soils, pure mineral or organic adsorbents in suspension have shown that the $\mathrm{pH}$ is a master variable. Among potentially toxic trace metals, zinc ( $\mathrm{Zn})$ is one of the most widespread contaminants in the environment
(Nriagu and Pacyna, 1988). It accumulates in soils by atmospheric deposition originating from smelting operations and by agricultural applications of sewage sludge and agrochemicals (Alloway 1990).

Zinc plays an essential role in cellular systems and enzymes (Silva and Williams, 1991). Zinc may be irreversibly fixed by clay through isomorphus substitutions or solid-state diffusion into the crystal structure of layer silicates (Adriano, 1986). Swift \& McLaren (1991) reported that adsorption and desorption strongly affect the bioavailability of heavy metals and therefore toxicity in soil. The type and stability of metal sorption complexes formed at solution-particle interfaces depend on the solution conditions $(\mathrm{pH}$ and ionic strength) and the solid phase present (Maarten and Sparks, 2004).

For adsorption, cations are held either through electrostatic attraction, thus giving rise to exchange with the surrounding ions, or by specific adsorption through surface complexation on organic and mineral subsurface. Zachara et al., (1998) reported that uptake of $\mathrm{Zn}$ (II) by calcite in sorption experiments may include adsorption processes, incorporation of $\mathrm{Zn}(\mathrm{II})$ into the calcite structure, and the formation of Zn-hydroxycarbonate precipitates. Whatever the mechanisms involved, retention in soils greatly determines the mobility and the behavaibility of heavy metals; it is therefore essential to improve our knowledge of this processes. In this study different type of soils have different chemical properties have been used. Our objectives were to:

(i) Identify the soil which has high capability to adsorbed $\mathrm{Zn}$.

(ii) Understand adsorption mechanism of these soils using different models.

(iii) Established correlation between adsorption behavior and adsorption capacity of these soils.

\section{MATERIALS AND METHODS}

Soils:

Six surface $(0-20 \mathrm{~cm})$ soil samples represent the major soil series used for agricultural production in Malaysia were sampled. The soils classification present in Table (1). The soils were selected to be truly

\footnotetext{
${ }^{1} \mathrm{KFU}$ college of agriculture, Dept. of Environmental and natural resources P.O.Box 420 alhassa 31982 Saudi Arabia ihawas@yahoo.com

Received July 31, 2008, Accepted August27, 2008
} 
representative of the area and to give wide variation in soil properties. The soil samples were air dried and ground to pass through a $2 \mathrm{~mm}$ sieve.

Soil $\mathrm{pH}$ was determined using 1:2.5 soil/water ratio. Organic carbon (OC) by dichromate oxidation method (Nelson and Sommer, 1982). The cation exchange capacity (CEC) were determined by leaching with neutral ammonium acetate solution (Piper 1947). Caexchange of the soils was determined by extraction with $0.1 \mathrm{M} \mathrm{KNO}_{3}$ of the $\mathrm{Ca}$ sorbed from $0.025 \mathrm{M} \mathrm{CaCl}_{2}$ (Mackay et al., 1986). Mineralogical composition of the soils was determined using x-ray diffraction analysis (Page et al. 1982).

Table 1. The classification of the studied soils

\begin{tabular}{lcrr}
\hline Soil & Soil Classification & Latitude (N) & Longitude (E) \\
\hline Sedu & Typic Sulfaquept & $2^{\circ} 30.238^{\circ}$ & $102^{\circ} 48.505^{\prime}$ \\
Segamat & Haplic Acrorthox & $1^{\circ} 56.287^{\circ}$ & $103^{\circ} 11.533^{\prime}$ \\
Kundor & Tropic Fluvaquent & $1^{\circ} 56.114^{\prime}$ & $103^{\circ} 10.916^{\prime}$ \\
Durian & Orthoic Tropudult & $1^{\circ} 50.443^{\prime}$ & $103^{\circ} 07.343^{\prime}$ \\
Melangit & Typic Paleudults & $6^{\circ} 05.287^{\circ}$ & $103^{\circ} 20.148^{\prime}$ \\
Betu Anam & Typic Paleudults & $6^{\circ} 31.097^{\circ}$ & $100^{\circ} 10.468^{\prime}$ \\
\hline
\end{tabular}

\section{Sorption experiment:}

Sorption isotherms were conducted at constant $\mathrm{pH} 7$ and room temperature. The sorption of $\mathrm{Zn}$ was determined by adding $25 \mathrm{~mL}$ solution containing each of $0,5,10,20,40,60$, and $100 \mathrm{mg} \mathrm{Zn}$ as zinc chloride $\left(\mathrm{ZnCl}_{2}\right)$ in $0.01 \mathrm{M} \mathrm{CaCl} 2.2 \mathrm{H}_{2} \mathrm{O}$ to $1 \mathrm{~g}$ soil in $50 \mathrm{ml}$ polypropylene test tube. Triplicate samples were prepared for each solution concentration. The tubes were mechanically shaken for $24 \mathrm{hrs}$ at $240 \mathrm{rpm}$ and room temperature $\left(25^{\circ} \mathrm{C}\right)$. Each sample was filtered through a Whatman No. 42 filter paper. The concentration of $\mathrm{Zn}$ in the filtrate was determined by ICP. The $\mathrm{Zn}$ sorption was calculated as difference between the $\mathrm{Zn}$ concentration in solution before and after equilibration. Two models, Freundlich and Langmuir isotherm models, have been used to study adsorption analysis. The Freundlich isotherm model was chosen to estimate the adsorption data according to the following formula:

$\mathbf{x} / \mathbf{m}=\mathbf{A} \mathbf{C}^{\mathbf{b n}}$ where $\mathrm{x} / \mathrm{m}$ is the amount of $\mathrm{Zn}$ retained by the soil in $\mathrm{mg} \mathrm{kg} \mathrm{g}^{-1}, \mathrm{C}$ is the equilibrium concentration of $\mathrm{Zn}$ in solution $\left(\mathrm{mg} \mathrm{L}^{-1}\right)$, $\mathrm{A}$ is the maximum retention in $\mathrm{m}^{3} \mathrm{~kg}^{-1}$ and the parameter $\mathrm{b}$ is bonding energy. A linear regression analysis was performed between $\log C$ and $\log (x / m)$. The slope and intercept were used to calculate $\mathrm{b}$ and $\mathrm{A}$ as well as to test differences among soils for Zn.

The $\mathrm{Zn}$ sorption isotherms were plotted using the mean quantity of $\mathrm{Zn}$ sorbed and mean $\mathrm{Zn}$ equilibrium concentration. The sorption data ere also plotted using the linear version of Langmuir equation:

$\mathrm{C} /(\mathrm{x} / \mathrm{m})=\mathbf{1} /\left(\mathrm{k}_{\mathbf{1}} \mathrm{k}_{\mathbf{2}}\right)+\mathrm{C} / \mathrm{K}_{\mathbf{1}}$

Where $\mathrm{C}$ is the equilibrium concentration of $\mathrm{Zn}$ in solution $\left(\mathrm{mg} \mathrm{L}^{-1}\right), \mathrm{x} / \mathrm{m}$ is the quantity of sorbed $\mathrm{Zn}(\mathrm{mg}$ $\mathrm{kg}^{-1}$ ) on soil, $\mathrm{k}_{1}$ is the adsorption maximum $\left(\mathrm{mg} \mathrm{kg}^{-1}\right)$, and $k_{2}$ is a constant related to bonding energy of $\mathrm{Zn}$ to soil $\left(\mathrm{m}^{3} \mathrm{~kg}^{-1}\right)$.

A linear regression analysis was performed between $\mathrm{C}$ and $\mathrm{C} / \mathrm{x} / \mathrm{m}$. The slope $\left(1 / \mathrm{k}_{1}\right)$ and intercept $\left(1 / \mathrm{k}_{1} \mathrm{k}_{2}\right)$ were used to calculate $\mathrm{k}_{1}$ and $\mathrm{k}_{2}$ as well to test differences among soils for $\mathrm{K}_{1}$ and $\mathrm{k}_{2}$.

\section{RESULTS AND DISCUSSIONS}

\section{Physico-chemical properties of soils:}

General physico-chemical properties of soils, used in this study, were greatly differed (Table2). The soils were very acid to slightly alkaline with the lowest $\mathrm{pH}$ value at 3.00 (Sedu) and the highest $\mathrm{pH}$ is 7.3 at Melangit soil. The soils texture varied from silty to clayey. The highest clay content $\left(870 \mathrm{~g} \mathrm{~kg}^{-1}\right)$ was found in Segamat series. Organic carbon range from 18 to $62 \mathrm{~g} \mathrm{~kg}^{-1}$ soil. The highest organic carbon was found in Durian series. The cation exchange capacity was relatively high ranged from 9.4 to $120 \mathrm{Cmol}_{\mathrm{c}} \mathrm{kg}^{-1}$. A very high CEC of Kundor soil $\left(120 \mathrm{cmol}(+) \mathrm{kg}^{-1}\right)$ is attributed to presence of high charge clay minerals and to the high content of organic matter. Exchangeable $\mathrm{Ca}$ range between 0.18 to $77 \mathrm{Cmol}_{\mathrm{c}} \mathrm{kg}^{-1}$. The highest exchangeable $\mathrm{Ca}$ was found dominating the exchange site of the Kundor soils.

Table 2. Selected physical and chemical properties of the studied soils

\begin{tabular}{|c|c|c|c|c|c|c|c|c|}
\hline Soil & $\begin{array}{c}\text { Depth } \\
\text { cm }\end{array}$ & $\begin{array}{l}\mathrm{pH} \text { in } \\
\mathrm{H}_{2} \mathrm{O}\end{array}$ & $\begin{array}{c}\text { Clay } \\
\mathrm{g} \mathrm{Kg}^{-1}\end{array}$ & *Texture & $\underset{\mathrm{g} \mathrm{Kg}^{-1}}{\text { Organic C }}$ & $\begin{array}{c}\text { CEC } \\
\text { Cmol }_{\mathrm{c}} \mathrm{kg}^{-1} \\
\end{array}$ & $\begin{array}{c}\text { Exchangable } \\
\text { Ca } \text { mmol }_{\mathrm{c}} \mathrm{kg}^{-1}\end{array}$ & $\begin{array}{c}\text { Mineralogy of the clay } \\
\text { fraction** }\end{array}$ \\
\hline Sedu & $0-20$ & 3.0 & 490 & $\mathrm{SiC}$ & 18.8 & 38 & 2 & $\mathrm{~K}, \mathrm{Q}, \mathrm{Gb}, \mathrm{S}, \mathrm{M}$, and $\mathrm{J}$ \\
\hline Segamat & $0-20$ & 4.9 & 870 & $\mathrm{C}$ & 21.0 & 36 & 11 & $\mathrm{~K}, \mathrm{Q}, \mathrm{Gb}$, and Go \\
\hline Kundor & $0-20$ & 4.9 & 750 & $\mathrm{C}$ & 45.1 & 120 & 77 & $\mathrm{~K}, \mathrm{Q}, \mathrm{M}$ and $\mathrm{S}$ \\
\hline Durian & $0-20$ & 4.4 & 480 & $\mathrm{SiC}$ & 62 & 31 & 2 & $\begin{array}{c}\mathrm{K}, \mathrm{Q}, \mathrm{Gb}, \mathrm{S}, \mathrm{M}, \mathrm{F} \\
\mathrm{M}+\mathrm{M}-\mathrm{ML} \text { and } \mathrm{M}+\mathrm{S}\end{array}$ \\
\hline Melangit & $0-20$ & 7.3 & 189.2 & $\mathrm{Si}$ & 5.4 & 9.4 & 0.18 & $\mathrm{~K}$, Calcite \\
\hline Betu Anam & $0-20$ & 5.4 & 630 & $\mathrm{C}$ & 15.7 & 42 & 21 & $\mathrm{~K}, \mathrm{Q}, \mathrm{M}$ and $\mathrm{F}$ \\
\hline
\end{tabular}

*C-clay, SiC- Silty clay, Si-silty

** K-Kaolinite, Gb- Gibbsite, Go- Goethite, F-Feldspar, M-Mica, Ml- Mixed layer, S-Smectite, Q-Quartz and J- Jarosite, CEC (Cation Exchange Capacity), O.C (Organic Carbon). 
The studied soils varied in the clay mineralogy (Table 2). In general, smectite, kaolinite, and mica were the most common clay minerals in most soil samples. The clay fraction of soils Sedu, Kundor and Durian was dominated by smectite with a moderate amount of kaolinite and mica. In contrast, Melangit soil was dominated by kaolinite and calcite. Most of these soils considered highly weathered soils and hence, low amounts of 2:1 minerals present. The clay fraction of Betu Anam soils consisted of nonphylosilicate minerals such as feldspar. Goethite was detected only in Segamat soils, whereas gibbsite was found in three soil (Sedu, Segamat and Durian). However, quartz occurred in all studied soils in very low amounts.

\section{Adsorption Mechanisms}

The amount of sorbed $\mathrm{Zn}$ by soil greatly varied and depended on the physico-chemical properties of used soils. Sorption isotherms of $\mathrm{Zn}$ for studied six soils are shown in Figure(1). All used soils showed a high sorption capacity at low concentration of zinc (0-30 $\mathrm{ppm})$. A sharp increase in the sorbed amount was noted with increasing of $\mathrm{Zn}$ concentration from 30 to $100 \mathrm{ppm}$ in three soils Sedu, Durian and Batu Anam. The soil pH significantly affected the exhibited sorption, being maximum of $\mathrm{Zn}$ sorption was at soil with $\mathrm{pH}$ value of 4.5 .

High increment in the amount of sorbed Zn by soils was in the order Melangit $>$ Kundor $>$ Segamat $>$ Sedu $>$ Durian > Batu Anam. The high adsorption of $\mathrm{Zn}$ in Melangit soil is attributed to the type of minerals present. Though, Melangit soil is silty with low CEC but, it has $\mathrm{pH}>7$, and dominated with calcite mineral these factors may have a high influence in increasing the retention of $\mathrm{Zn}$. On the other hand, Kundor soil attributed to high content of clay fraction and exchangeable $\mathrm{Ca}$ and high CEC. Hanafi and Sjiola (1998) have shown that CEC is the most important factor controlling the adsorption of $\mathrm{Zn}$ in acid tropical soils. Whereas, Wahba and Zaghloul (2007) have reported a comparison between clay minerals and calcite and showed that calcite gave higher adsorption capacity compared with montmorillonite or kaolinite. For the $\mathrm{CaCO}_{3}$ Papadopoulos and Rowell (2006) found that the precipitation of $\mathrm{CdCO}_{3}$ on calcite predominates at higher $\mathrm{Cd}$ additions, whereas at low $\mathrm{Cd}$ additions an ideal surface solid solution is formed between $\mathrm{CdCO}_{3}$ and $\mathrm{CaCO}_{3}$.

Statistical parameter (r) was used to find the best fit of $\mathrm{Zn}$ sorption for three physicochemical equations Freundlich, Langmir and the second order equations. A comparison of the coefficient of regression $\left(\mathrm{r}^{2}\right)$ for the three isotherms is shown in Table3. For the Langmuir isotherm $\mathrm{r}^{2}$ have a range from 0.411 to 0.999 with an average value of 0.760 . The range for $r^{2}$ by Freundlich is 0.349 to 0.926 and the average is 0.7205 . For the second ordered equation isotherm the range of $\mathrm{r}^{2}$ varied 0.366 to 0.997 with an average value of 0.774 . Results obtained indicated that all equations showed similar average $\left(\mathrm{r}^{2}\right)$. Generally Langmuir equations was better to describe the relation between $\mathrm{Zn}$ concentration in equilibrium solution and its sorption by soils because of higher $r^{2}$ values compared to Freundlich equations (Table 3). Therefore, it could be concluded that Langmuir equations fits $\mathrm{Zn}$ sorption better. Al-Ameri (2001) in has study on the calcareous soils from Baghdad reported similar conclusions.

Table 3. Correlation using different equations Langmuir (L) and Freundlich (F) and second order equation

\begin{tabular}{lccc}
\hline Soils & \multicolumn{3}{c}{ Isotherm } \\
\cline { 2 - 4 } & $\mathbf{r}^{2}(\mathbf{F})$ & $\mathbf{r}^{2}(\mathbf{L})$ & $\mathbf{r}^{2}$ \\
\hline Sedu & 0.903 & 0.821 & 0.845 \\
Segamat & 0.349 & 0.820 & 0.366 \\
Kundor & 0.857 & 0.999 & 0.755 \\
Durian & 0.551 & 0.514 & 0.785 \\
Melangit & 0.737 & 0.997 & 0.898 \\
Betu Anam & 0.926 & 0.411 & 0.997 \\
\hline
\end{tabular}

The Adsorption coefficient $\left(\mathrm{k}_{1}-\mathrm{b}\right)$ and bonding energy $\left(\log \mathrm{A}-\mathrm{k}_{2}\right)$ for both Freundlich and Langmuir are shown in (Table, 4). $\mathrm{Zn}$ adsorption showed the highest $\log$ A value was $2.865 \mathrm{~m}^{3} \mathrm{~kg}^{-1}$ for Melangit soil and the lowest was $0.062 \mathrm{~m}^{3} \mathrm{~kg}^{-1}$ for Betu Anam soil. The high value of $\log \mathrm{A}$ indicated that the soil has high affinity to sorb $\mathrm{Zn}$ in comparison to the other soils with low value of $\log$ A. In addition Melangit soil has $\mathrm{pH}>$ 7 , and rich in calcite this could be an indication of precipitation of $\mathrm{Zn}$ as it explained by Ford and Sparks (2000) and Ford et. al. (1999). Who reported that at higher solute concentrations and $\mathrm{pH}>6.5, \mathrm{Zn}$ can be incorporated into neo-formed precipitates, formed at the surfaces of phyllosilicate minerals. These surface precipitates are formed at solution conditions undersaturated with respect to homogeneous precipitation. Metwally et. al.,(1993) suggested that aqueous $\mathrm{Zn}^{++}-\mathrm{Zn}(\mathrm{OH})_{2}$ aqueous controlled the solubility of zinc in soil and clay mineral suspensions at $\mathrm{pH} 7.5$ 9.0.

The bonding energy (b) values ranged from 0.269 to 1.1793. Most soils showed low b values except Betu Anam soil. The difference between soils could be related to the physiochemical properties such as acidicity, fine texture and relatively high CEC. The low $\mathrm{b}$ indicate that $\mathrm{Zn}$ adsorbed on the surface in less than one layer and the bonding is could be $\mathrm{Zn}-\mathrm{Zn}$. Maarten and Sparks, (2004) suggested that in acidic to near 

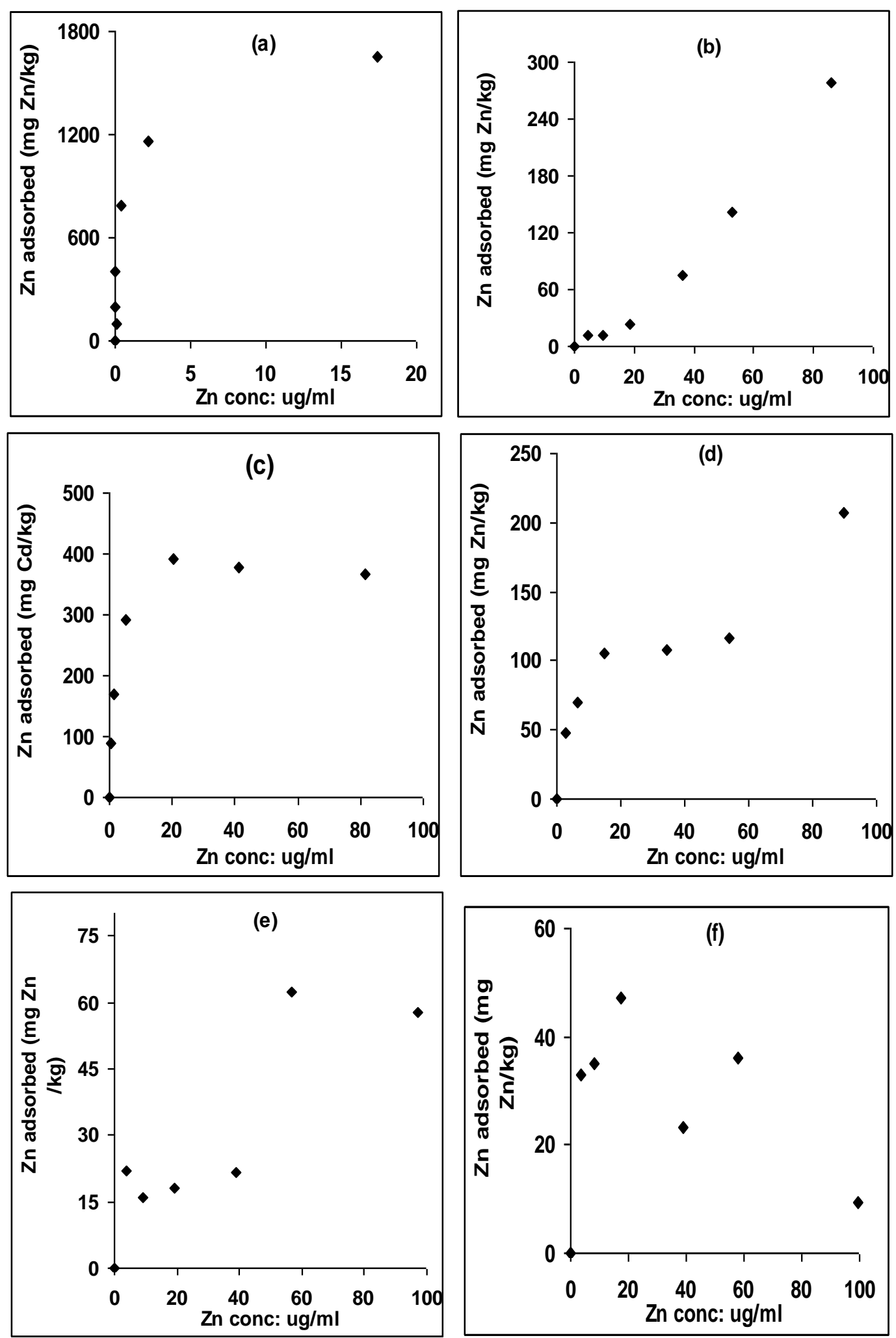

Figure 1. Zn sorption isotherms for (a) Melangite (b) Batu Anam (c) Kundur (d) Sedu (e) Durian (f) Segamat soils 
Table 4. Adsorption coefficient $\left(\log A-k_{2}\right)$ and bonding energy $\left(b-k_{1}\right)$ for both Freundlich and Langmuir equations

\begin{tabular}{lcccc}
\hline & \multicolumn{2}{c}{ (Freundlich) } & \multicolumn{2}{c}{ (Langmuir) } \\
\cline { 2 - 5 } Soil Name & $\log \mathbf{A}$ & $\mathbf{b}$ & $\mathbf{K}_{\mathbf{2}}$ & $\mathbf{K}_{\mathbf{1}}$ \\
\hline Sedu & 1.5466 & 0.3521 & 0.0548 & 0.207091 \\
Segamat & 1.7973 & 0.2686 & 0.7401 & 0.009812 \\
Kundor & 2.1441 & 0.2779 & 0.9539 & 0.376946 \\
Durian & 0.9457 & 0.3697 & 0.2295 & 0.078481 \\
Melangit & 2.8651 & 0.3850 & 1.8788 & 1.697217 \\
Betu Anam & 0.0621 & 1.1793 & 0.0067 & 0.212256 \\
\hline
\end{tabular}

neutral environments, $\mathrm{Zn}$ partitioning to phyllosilicate surfaces mainly occurs by electrostatic interactions, due to a net negative structural charge developed within the octahedral layers of phyllosilicates and by specific chemical binding to hydroxyl edge sites.

Similar result was found with Langmuir equation where it shows that Melangit soil has the highest adsorption coefficient $\left(\mathrm{k}_{1}, 1.697\right)$, moreover, bonding energy $\left(k_{2}\right)$ was higher in Langmuir than Freundlich equation for Melangit soil. Because of the Langmuir is liner equation it is better to explained the adsorption situation.

\section{CONCLUSION}

It is observed from the present study that zinc sorption varied greatly between soils. Evaluation of the adsorption isotherms tested, Langmuir can successfully be explained by a simple model that gave the best fit followed by Freundlich isotherm. The sorption process was found to be a physio-sorption process as seen from the apparent energy of adsorption.

\section{ACKNOWLEDGMENTS}

This work was supported by funds from King Faisal University as a scientific connection with Putra University in Malaysia. The thanks also extended to the Soil Science department and Environmental Science in Putra University for full cooperation and assistance.

\section{REFERENCES}

Adriano, D. C. (1986). Trace elements in the terrestrial environment. Springerverlag, New Yourk.

Al-Ameri, B. H. (2001). Behavior and efficiency of some zinc fertilizers in calcareous soils. M.Sc. Thesis. Agric.College, Univ. of Baghdad, Iraq.(in Arabic).

Alloway, B. J. (1990). Heavy Metals in Soils, Blackie, London, pp:333.

Ford R. G. and D.L. Sparks (2000). The nature of Zn precipitates formed in the presence of pyrophyllite. Environ. Sci. Technol. 34, 2479-2483.

Ford R. G., A.C. Scheinost, K.G. Scheckel, and D.L. Sparks (1999). The link between clay mineral weathering and structural transfor-mation in $\mathrm{Ni}$ surface precipitates. Environ. Sci. Technol. 33, 3140-3144.
Hanafi and Sjiola (1998). Cadmium and zinc in acid tropical soils: I. Soil physio-chemical properties effect on their adsorption. Commun Soil Sci. Plant Anal. 29(11-14), 1919-1931.

Igwe, J.C.; E.C. Nwokennaya,. and A.A. Abia, (2005). The role of $\mathrm{pH}$ in heavy metal detoxification by bio-sorption from aqueous solutions containing chelating agents. African Journal of Biotechnology,4: 1109-1112.

Maarten, N. and D. L. Sparks (2004). Effect of iron oxide coatings on zinc sorption mechanisms at the claymineral/water interface. Journal of Colloid and Interface Science 276: 13-23.

Mackay, A. D., J. K. Syers, R. W. Tillman, and P.E.H. Gregg (1986). A simple model to describe the dissolution of phosphate rock materials in soil. Soil Sci.Am. J. 50:291296.

Metwally, A.I., A. S. Mashhady, A. M. Falatah, M. Reda (1993). Effect of $\mathrm{pH}$ on Zinc Adsorption and Solubility in Suspensions of Different Clays and Soils. Earth and Environmental Science. 156(2):131 - 135

Muhamad, N.; J. Parr,; D.M. Smith; and D.A. Wheatley (1998). Adsorption of heavy metals in slow sand filters. In: Proceeding of the WEDC conference on sanitation and water for all $\left(24^{\text {th }}, 1998\right.$, Islamabad, Pakistan $)$, p. 346-349.

Nelson, D. W., and L. E. Sommers (1982). Total carbonate, organic matter, pp. 539-549, in: A. L. Page, R. H. Miller, and D. R. Keeny, eds. Methods of soil analysis. American Socity of Agronomy, Madison, Wisconsin, USA.

Nriagu J.O, J.M. Pacyna, (1988). Quantitative assessment of worldwide contamination of the air, water, and soil with trace metals. Nature 333: 134-139.

Papadopoulos, P. and D. Rowell (2006). The reactions of cadmium with calcium carbonate surfaces. European, J.Soil Sci., 39: 23-36.

Piper, C. S. (1947). Soil and plant analysis. Hassall Press, Adelaide, 42:165-175.

Shuman, L. M., (1975). The Effect of Soil Properties on Zinc Adsorption by Soils. Soil Sci Soc Am J 39:454-458.

Silva J.J.R. Fráusto da and R.J.P. Williams (1991). The Biological Chemistry of the Elements, Oxford Univ. Press, New York.

Swift, R.S., and R.G. McLaren (1991). Micronutrient adsorption by soil and soil colloids. p. 257-292. In F.H. Bolt et al. (ed.) Interactions at the soil colloid-soil solution 
interface. Part 2. Kluwer Academic Publishers. Dordrecht, The Netherlands.

Uzun, I. and, F. Guzel, (2000). Adsorption of some heavy metal ions from aqueous solution by activated carbon and comparison of percent adsorption result of activated carbon with those of some other adsorbents. Turkish Journal of Chemistry, 24: 291-297.
Wahba M. M. and A.M. Zaghloul (2007). Adsorption characteristics of some heavy metals by some soil minerals. Journal of Applied Sciences Research, 3(6): 421-426.

Zachara J.M., J.A. Kittrick, L.S. Dake, and J.B. Harsh (1998). Solubility and Surface Spectroscopy of Zinc Precipitates on Calcite. Geochim Cosmochim. Acta 53, 9-19. 


\section{الملخص العربي}

\section{إمتصاص الزنك في بعض الترب الطينية في ماليزيا}

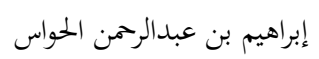

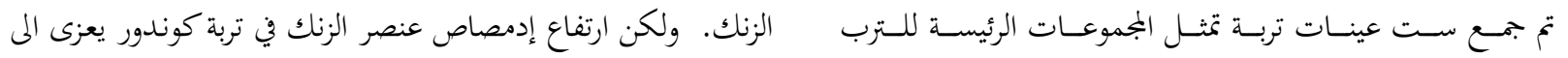
المستخدمة في الإنتاج الزراعي في ماليزيا, لدراسة قدرة إدمصاص الترب خصائص التربة. فالمتوى العالي من الطين و السعة التبادلية الكاتيونية

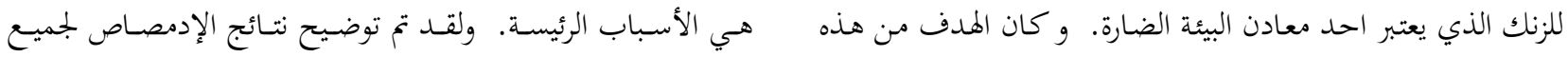

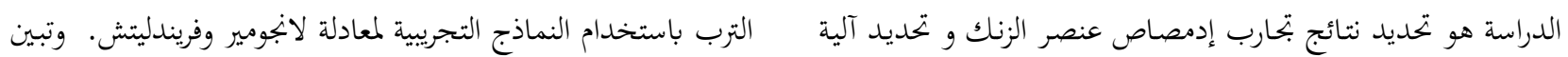

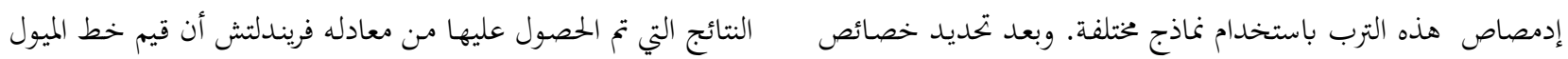
التربة،تم الحصول على منحنى الإدمصاص عن طريق إضافة ستة محاليل (R) أعلى من تلك التي تم الحصول عليها باستخدام معادلة لانجمير

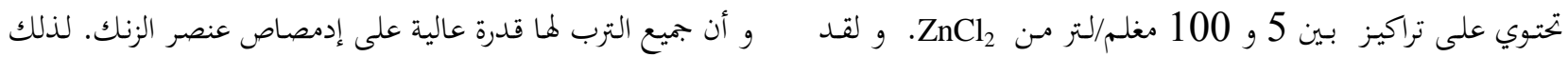

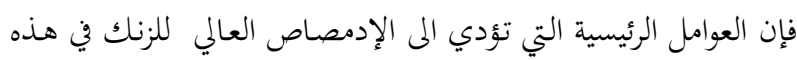

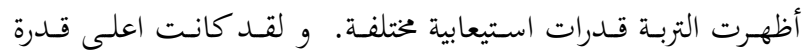
الترب الطينية هي الترسيب و الإدمصاص الأيوني.

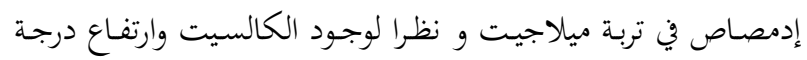
الاس الميدروجيني, لذا فان العامل الرئيس للنسبة العالية هو ترسيب 